\title{
Creating a custom-published textbook to facilitate curriculum change: An example from advanced accounting
}

\author{
Dawn W. Massey \\ Fairfield University, dmassey@fairfield.edu \\ Joan Lee (Van Hise) \\ Fairfield University, jlee@fairfield.edu
}

Follow this and additional works at: https://digitalcommons.fairfield.edu/business-facultypubs Copyright 2003 Emerald

\section{Peer Reviewed}

\section{Repository Citation}

Massey, Dawn W. and Lee (Van Hise), Joan, "Creating a custom-published textbook to facilitate curriculum change: An example from advanced accounting" (2003). Business Faculty Publications. 88. https://digitalcommons.fairfield.edu/business-facultypubs/88

\section{Published Citation}

Massey, Dawn and Joan Van Hise. 2003. "Creating a custom-published textbook to facilitate curriculum change: An example from advanced accounting." Advances in Accounting Education: Teaching and Curriculum Innovations, Volume 5, pp. 243-261.

This item has been accepted for inclusion in DigitalCommons@Fairfield by an authorized administrator of DigitalCommons@Fairfield. It is brought to you by DigitalCommons@Fairfield with permission from the rightsholder(s) and is protected by copyright and/or related rights. You are free to use this item in any way that is permitted by the copyright and related rights legislation that applies to your use. For other uses, you need to obtain permission from the rights-holder(s) directly, unless additional rights are indicated by a Creative Commons license in the record and/or on the work itself. For more information, please contact digitalcommons@fairfield.edu. 


\title{
CREATING A CUSTOM-PUBLISHED TEXTBOOK TO FACILITATE CURRICULUM CHANGE: AN EXAMPLE FROM ADVANCED ACCOUNTING
}

\author{
Dawn W. Massey* \\ Assistant Professor of Accounting \\ Charles F. Dolan School of Business \\ Fairfield University \\ 1073 North Benson Road \\ Fairfield, CT 06430 \\ Phone: 203/254-4000 X 2844 \\ FAX: 203/254-4105 \\ E-mail: $\underline{\text { dmassey@mail.fairfield.edu }}$
}

\author{
Joan Van Hise \\ Assistant Professor of Accounting \\ Charles F. Dolan School of Business \\ Fairfield University \\ 1073 North Benson Road \\ Fairfield, CT 06430 \\ Phone: 203/254-4000 X 3015 \\ FAX: 203/254-4105 \\ E-mail: jvanhise@mail.fairfield.edu \\ *Corresponding Author
}

Data Availability: Data are available upon request to the authors. 


\begin{abstract}
According to Smith and DeRidder (1997), faculty select texts mainly for their comprehensibility to students and the timeliness of text material they contain. Further, Foran and Olds (2002) suggest students use textbooks as their primary means of acquiring background knowledge. However, many accounting texts have failed to keep abreast with changes in accounting practice and education (Rebele et al. 1998), creating an important barrier for accounting educators who desire to effect curriculum change. We illustrate how faculty can overcome this barrier and potentially make their courses more interesting and/or informative for students (Apostolou et al. 2001). By capitalizing on recent advances in technology, faculty can create custom-published textbooks that support their curriculum revision efforts.

Based on our successful experiences in creating a custom-published textbook to support a revised Advanced Accounting course, we describe not only the logistics involved in, but also the benefits and challenges associated with, creating a custom-published text. The insights we gained can provide guidance for faculty members who want to revise their courses but have been constrained because they could not find an available textbook to support their curriculum revision activities.
\end{abstract}




\section{CREATING A CUSTOM-PUBLISHED TEXTBOOK TO FACILITATE CURRICULUM CHANGE: AN EXAMPLE FROM ADVANCED ACCOUNTING}

\section{INTRODUCTION}

Leaders in both the academic and professional sectors of the accounting profession have been calling for changes in accounting education for more than a decade (e.g., AECC 1990; AICPA 1999; Albrecht and Sack 2000; Bedford Committee 1986; Big 8 1989; IMA 1994, 1999; Stone 2001). However, an important challenge facing educators interested in effecting curriculum change has been the failure of many textbooks to keep abreast of changes in accounting practice and education (Rebele et al. 1998, 42). This challenge is particularly salient not only because textbooks tend to drive course content and delivery (e.g., Albrecht and Sack 2000, 53; Farr 1987, 86), but also because students rely on texts as their primary source for background knowledge (Foran and Olds 2002, $37)$.

Due to recent advances in technology, educators are now able to create custom-published textbooks to overcome this challenge and potentially make their courses more interesting and/or informative (Apostolou et al. 2001). Custompublished textbooks include information that educators select especially for inclusion in their course text. The information can cover a broad spectrum of topics - accounting, finance, general business, etc. - and faculty can draw 
textbook materials from a wide array of sources - professional, practitioner, academic, etc. Accordingly, custom-published textbooks afford faculty the opportunity to tailor text materials to fit the course, rather than tailoring the course to fit available textbooks (c.f., Farr 1987, 88).

In this paper, we chronicle our experiences in creating a custom-published textbook to support our Advanced Accounting course. We offer our experiences in Advanced Accounting as an example to guide any accounting faculty member in creating a custom-published textbook to support their teaching in any course. We begin in the next section, by reviewing the literature related to textbook selection and use in accounting. In section three, we discuss the logistics involved in creating a custom-published textbook. In section four, we discuss the benefits and challenges associated with creating a custom-published textbook, drawing on feedback we have gathered from students and faculty. Finally, in section five, we present our overall conclusions.

\section{LITERATURE REVIW}

Very little research has addressed the issue of textbook selection in accounting. However, Razek et al. (1982) suggest that comprehensibility is the most important quality an accounting textbook can possess. Further, using a sample of four intermediate accounting textbooks, Adelberg and Razek (1984) 
judge that the effectiveness of communication technique is a useful way of evaluating the understandability of accounting textbooks.

Smith and DeRidder (1997) surveyed 237 faculty randomly selected from Hasselback's 1995 Accounting Faculty Directory to investigate the protocol used for textbook selection (i.e., individual versus group decision by course) and the criteria used for textbook selection, among other issues. Results indicate that textbook selection tends to be a group decision for introductory and intermediate accounting courses. For upper-level accounting courses (e.g., advanced accounting, tax, and accounting information systems) the decision tends to be an individual decision. According to respondents in Smith and DeRidder's (1997, 367) survey, the top four textbook selection criteria are: comprehensibility to students, timeliness of text material, compatibility between text and homework problems, and exposition quality of the text. Taken together, findings in all three studies suggest that faculty should choose textbooks that maximize, "the efficiency and effectiveness of subject matter assimilation by students" (Smith and DeRidder 1997, 368).

Unfortunately, additional research suggests accounting textbooks have failed to keep up with curriculum changes in general (Rebele et al. 1998, 42) as well as in certain courses (Advanced Accounting [Massey and Van Hise 2001, 12], Auditing [Knechel 2000, 709], Intermediate Accounting [Catanach et al. 2000, 587; Ketz and Miller 1996, 14-15], and Management Accounting [Böer 
2000, 332]). Given that faculty's reliance on textbooks drives the content and delivery of accounting courses (Albrecht and Sack 2000, 53), professors have been somewhat constrained in covering in their courses only what the textbooks support.

To overcome the inability of texts to keep abreast of curriculum changes and meet the diverse needs of faculty seeking to innovate their courses, this paper suggests creating custom-published textbooks to support curriculum revisions in accounting education. We describe our experiences in developing a custompublished textbook to support our curriculum innovation in Advanced Accounting. Our experiences suggest that development of the custom-published text has the added benefit of allowing course content and delivery to drive accounting textbooks, rather than vice versa (c.f., Farr 1987, 88).

\section{LOGISTICS OF CREATING A CUSTOM-PUBLISHED TEXTBOOK} Preliminary Considerations

\section{General}

Before creating a custom-published textbook, it is important to note that the publisher's costs for putting together a custom-published textbook are likely to make the book's cost prohibitive to the students unless faculty expect to use at least the number of copies of the text required for break-even. Accordingly, in situations where course enrollments number less than the break-even quantity for 
the custom-published book, an important tradeoff for faculty to consider is whether they can/will use the book in a sufficient number of semesters to enable students to afford the custom-published textbook (i.e., timeliness versus affordability).

\section{An Example from Advanced Accounting}

For instance, given the size and quantity of materials included in the most recent version of the custom-published textbook we created for Advanced Accounting (A critical analysis of advanced accounting issues, 2001), ${ }^{1}$ the cost of the text would increase substantially if our annual enrollment were to fall below 100. Because change in accounting occurs rapidly, one advantage we have found with using a custom-published textbook is our ability to revise the text annually, so that we minimize errors and omissions (Smith and DeRidder 1997, 382) as related to changes in course topical areas. However, because standard textbook revisions typically occur only once every three years, we decided that even if our annual enrollments dropped to one-half of the number required for break-even (i.e., 50), compiling and using a custom-published textbook every other year would still be worthwhile. That is, we concluded that the information in a biennially revised custom-published text would be timelier than the information contained in a traditional text with a triennial revision cycle. 


\section{Step 1: Settle on Course Content and Delivery}

Settling on course content and delivery is not a trivial process. Indeed, an entire academic paper could be devoted to a prescriptive discussion about the appropriate content and delivery for accounting courses (see, e.g., AICPA 1999, 2000; Albrecht and Sack 2000; IMA 1994, 1999; Robert Half International, Inc. 2001). Accordingly, we will keep our remarks brief by relying on recently published related works by the leaders in our profession.

In settling on course content and delivery, some preliminary points need to be made. First, there is not a single "best" content and/or delivery approach that applies to every school and course (Albrecht and Sack 2000, 60). Faculty need to tailor courses around the mission statement of the accounting unit to capitalize on the strengths of the school and department. Second, in order to make course-level decisions, there is a presumption that faculty members have already engaged in preliminary assessment activities (Albrecht and Sack 2000, 60-64; Catanach et al. 2000, 584-587). That is, accounting faculty wishing to revamp their courses have already performed such work as evaluating the environment the department is facing and all degrees the department offers.

In deciding upon course content and delivery, we suggest faculty consult Albrecht and Sack (2000, 63), who recommend that in making course-level changes, faculty answer the following questions: 
1. Is what we are teaching and the level at which we are covering topics really important in the business world today...?

2. Are we teaching important concepts in the most efficient and effective way-that is, are we using the most effective pedagogy in our teaching?

Faculty also can find suggestions for course content and delivery in the recent work of several professional organizations (e.g., AICPA 1999, 2000; IMA 1999; Robert Half International, Inc. 2001). For instance, in the report for its Vision Project (AICPA 1999), the AICPA identifies five competencies that successful future accountants will need in order to sustain a "competitive and differential advantage in the marketplace” (AICPA 1999, 12). They are: 1) communications and leadership skills; 2) focus on the customer, client and market; 3) technological adeptness; 4) interpretation of converging information; and 5) strategic and critical thinking skills. Some of these are best developed through course content while others are best developed through course delivery. Finally, we suggest faculty considering curriculum change consult with their peers. Anyone considering curriculum revision should review recent literature for published works. Additionally, online resources, such as the American Accounting Association's (AAA's) website, include a wide variety of pedagogical resources (e.g., see http://accounting.rutgers.edu/raw/aaa/teach.htm). 
By consulting such resources, educators considering revising the content and delivery of their courses may benefit from the experiences of their colleagues.

\section{An Example from Advanced Accounting}

Before we set out to revise our Advanced Accounting course, our department had made several important program-wide decisions. First, because the 150-hour requirement is not effective in two neighboring states for several years, our department decided to continue to offer a four-year accounting degree that prepares students for entry to both the profession as well as a 150-hour BS/MBA program. Second, non-accounting majors, notably finance majors, at our university can pursue a minor in accounting by taking five accounting courses (two introductory level courses, two intermediate level courses and one upperlevel course). Our department decided that Advanced Accounting was the course that we could best tailor to meet the informational needs of the accounting minors and, therefore, draw students to study accounting. Bearing these important programmatic considerations in mind, we set out to decide upon what we would teach in our revised Advanced Accounting course and how we would teach it.

To address Albrecht and Sack's first question on topical coverage, we began by reviewing the accounting educational literature. Only Smith and Smith (1991) propose an overall curriculum revision in the Advanced Accounting 
course. They recommend (Smith and Smith 1991, 31) that Advanced Accounting courses cover "Interpretive Accounting Standards", which would include:

Interpretive analysis of FASB accounting standards. This goes beyond the straightforward analysis of FASB standards. It involves the critical analysis of these standards to determine how it is possible to work around them and present better accounting results.

Although more than ten years have elapsed since Smith and Smith made their recommendations, not one study describing an innovation in the Advanced Accounting course appears in the accounting education literature since that date. A few studies have addressed specific aspects of the Advanced Accounting course, including: Kimmel 1995 and Stout and Schweikart 1989. Notably, these studies suggest that Advanced Accounting is particularly well suited for development of critical thinking skills (Kimmel 1995) and that it is an appropriate outlet for international coverage (Stout and Schweikart 1989). As a result, our revised course content emphasizes not only "interpretive analysis of FASB accounting standards" (Smith and Smith 1991, 31), but also international accounting issues in Advanced Accounting.

Since accounting courses in general (Albrecht and Sack 2000) and ours in particular service an increasing number of non-accounting majors, we also wanted to include in Advanced Accounting topics that would be "important in the business world today" (Albrecht and Sack 2000, 63). Specifically, because an 
explosion of market investors and their resultant power together with globalization are two key drivers of change in today's business environment (Albrecht and Sack 2000, 5-6), we focus on all aspects of investing in an international marketplace rather than a narrow focus on business combinations.

To address Albrecht and Sack's second question, "Are we using the most effective pedagogy?", we changed the format of the course in three ways. Our revised course format also allowed us to shift the focus in our revised Advanced Accounting course from the mechanical recording of a transaction to an analysis of the adequacy of the accounting treatment for the transaction.

We conduct class largely as a seminar. We allow students to "learn concepts and principles by discovering them" (Cunningham 1996, 57). We expect students to arrive for class having read and analyzed relevant course materials. We form student teams and move much of the procedural work outside of the classroom. We still require students to master basic procedures, (such as those required to consolidate or translate financial statements,) but they develop those skills using out-of-class group assignments. By conducting class as a seminar and using out-of-class group assignments, we have been able to free up class time to discuss and justify the use of various accounting alternatives (e.g., a comparison of investments carried under the equity method as opposed to fair value). Finally, we include in the course two active learning activities aimed at developing 
students' oral communication and critical thinking skills: oral debates and an international accounting presentation.

\section{Step 2: Select Materials for Inclusion in Text that Support Course Content and Delivery}

After settling upon course content and delivery, the second step involved in developing a custom-published textbook is to select materials to include in the text that will support the content and delivery of the course. To that end, we found four particularly useful sources of information: 1) textbooks, 2) professional and business publications, 3) articles describing the results of academic research, and 4) resources posted on reliable Internet web sites.

Traditionally, course materials in accounting have tended to ignore other subject areas, resulting in "silo" coverage of accounting topics (Albrecht and Sack 2000, 51). In reviewing textbooks to support desired course content and delivery, educators need not limit themselves to accounting textbooks. In particular, materials drawn from information systems and finance texts would seem especially useful (Albrecht and Sack 2000, 62).

Educators can include practitioner input in curriculum development (Albrecht and Sack 2000, 50; Novin et al. 1997, 348), by using professional publications, especially when presenting new and/or difficult topics. These resources are particularly useful ones to include in custom-published textbooks 
because many of them are available for educational use, free of charge. ${ }^{2}$ Another way to include in accounting courses input from the business community is to rely on articles drawn from business periodicals (e.g., Wall Street Journal, Business Week, etc.) (c.f, Foran and Olds 2002, 28).

Articles describing results of academic research is a third resource for materials educators can include in their custom-published textbooks. Indeed, researchers suggest educators attempt to integrate academic accounting research and accounting education (e.g., Birnberg 2000; Cohen, Pant and Sharp 2000, 94; Knechel 2000, 709). Educators can identify articles that describe relevant results of academic research by searching academic databases (e.g., ABI/Inform, Infotrac, Proquest, etc.). Faculty can include in the custom-published textbook a subsample of the most readable of these articles (whether in accounting or some other related field) to integrate academic research and accounting education.

Finally, educators need not limit themselves to information found in traditional printed matter (Foran and Olds 2002, 28). Rather, faculty can draw materials from postings to Internet web sites (e.g., the AICPA's web site, the FASB's web site, Business Week's web site, etc.). Like professional publications, information posted on the Internet is particularly useful to include in custompublished textbooks because much of it is in the public domain, and accordingly, available for inclusion in the text, free of royalties. 
Students accrue significant benefits from using a multitude of resources in a custom-published textbook. First, students learn that there are various resources they can consult when facing a professional problem (Foran and Olds 2002, 29). Second, because different authors often present varying viewpoints on the same controversial issue, students come to understand that some issues must be resolved by using judgment (c.f., Foran and Olds 2002, 29). In this way, the materials included in a custom-published textbook can help foster students' critical thinking skills and prepare them for their role in the uncertain business world.

\section{An Example from Advanced Accounting}

In developing a custom-published textbook to support the content and delivery of our revised Advanced Accounting course, we considered materials from the above-described sources for inclusion in our text. The table of contents for the most recent edition of our custom published textbook appears in Table 1.

\section{(Insert Table 1 here.)}

The 2001-2002 edition of our custom-published textbook contained 566 pages in nine chapters. We drew materials from five textbooks (across two different publishers) and seven professional/business sources. Owing to the emerging nature of accounting for derivatives and business combinations, we use several professional and business publications to cover these topics. In order to 
keep the text to a manageable number of pages and therefore minimize duplicating costs for the custom-published textbook, we did not include articles describing the results of academic research in the custom-published textbook. Instead we posted them to our library's electronic reserves system for students to access and review in preparing for their debates. Finally, our custom-published textbook includes one article drawn from a reliable Internet web site (i.e., an article from Fortune magazine on-line).

\section{Step 3: Agree on a Publisher to Assemble and Deliver the Custom-Published Textbook}

The last step in adopting the custom-published text is to select a publisher to compile the text. We believe, it is best to choose the publisher from whom the instructor draws the majority of the materials in order to decrease the cost of the completed text. It is important to work with a publisher who is willing to devote the resources necessary to obtain permissions from others for inclusion of their work in the custom-published text.

As a rule, the more sources selected, the greater the cost of publication. In addition, inclusion of materials from different publishers increases the cost. While increasing the number of pages included from a given source also increases cost, the increase is usually less than including the same additional number of pages from a different source. 
A final consideration is lead-time. It can vary considerably depending on the publisher the faculty choose and the time of year. We typically need a minimum of four to five months to screen and select materials, negotiate with the publisher, obtain all necessary permissions, and publish the text. Additional time would be necessary if the department has not already engaged in preliminary assessment activities.

\section{An Example from Advanced Accounting}

The first time we compiled our custom-published text for Advanced Accounting, all the textual material we included was from one publisher and we chose that publisher to produce the text. In subsequent revisions, we expanded our search for the best materials and now include textual material from other publishers as well as more extensive non-textual material. One of the reasons we were able to expand our course materials was that we had a very supportive editor who was willing to spend the time necessary to contact the copyright holders on the new materials and obtain permission to include them in the text.

While we have been able to maintain a relatively constant cost by judiciously choosing materials from the public domain, the inclusion of material from outside the publishers' offerings has lengthened the lead-time necessary to prepare the text. We normally submit the list of materials we intend to include to our publisher by July $1^{\text {st }}$ if the materials come from outside sources, and by July 
$15^{\text {th }}$ for materials in the publishers' offerings. The books typically arrive at the bookstore by the first of September. Again, without tremendous cooperation from our editor, we could not get the books out on such a tight timetable.

\section{ANALYSIS OF PROS/CONS BASED ON OUR EXPERIENCES}

As with any pedagogical innovation, our experiences together with those of our students provide a wealth of knowledge about the benefits and challenges associated with compiling and utilizing a custom-published textbook.

The use of custom-published textbooks as a mechanism to support curriculum change

A clear advantage of using custom-published texts to facilitate curriculum revision is that faculty can design texts to support custom-created curriculum. In the past year, we have received inquiries from colleagues at several universities about our course revision. Many indicated that they had used different books over the years in order to support their curriculum but were not satisfied with the results. As one colleague wrote, "I have been teaching Advanced for many years, and I have never been satisfied with the textbooks or coverage."

Consistent with Albrecht and Sack's $(2000,53)$ finding that textbooks drive the content and delivery of accounting courses, a key question from each faculty member interested in our course revision was whether our text was 
available for use by other faculty. Thus far, the faculty members who have reviewed our text have provided us with positive feedback. For instance, one faculty member noted, "I used [one of the traditional Advanced Accounting textbooks included in the custom-published text] the first year I taught Advanced and [another of the traditional Advanced Accounting textbooks included in the custom-published text] the second year and there are things that I liked about each. Thus, I really liked your text because it incorporates the best of both." From the student perspective, we also judge our custom-published textbook as successful in its ability to support the changes to the content and delivery of our Advanced Accounting course. One former student recently sent us an unsolicited letter stating, "I am working in treasury finance at Merrill Lynch's banks at this time and I utilize all of the derivatives related accounting concepts that we covered in your class. I keep the textbook for that class on my desk and it has been a useful resource for me as well as many of my co-workers and superiors." Additionally, in the most recent year for which we have data, 2001$2002,80 \%$ of the students responding to the standardized university evaluation form indicated that they agreed/strongly agreed with the following statement: "The textbooks and/or other materials I bought for the class aided my learning." This result is noteworthy because our custom-published textbook is the only source that we require our students to purchase. 
Since we tied our revision of the Advanced Accounting curriculum to the introduction of a custom-published text in the course, it is difficult to separate the effects of the revision from the effects of the custom-published text. It is clear that the revision would not have been possible without the introduction of the custompublished text. Consequently, we also evaluate the success of the text in terms of the success of the revision of the course. Since we introduced the custompublished text as part of the revised course, students have consistently rated the course as excellent or above average in attaining the stated objective of critically assessing: (1) the adequacy of current accounting treatment for various levels of investment; and (2) the accounting implications associated with investing in a global marketplace. In the 2001-2002 year, over 93\% of students gave the course an excellent or above average rating.

On the downside, the various faculty members who teach each course may not all agree on course curriculum. Because Smith and DeRidder $(1997,372)$ suggest that unlike the text selection process for upper-level courses, the selection of texts for introductory and intermediate courses is usually a group decision, it is likely to be harder to utilize a custom-published textbook that pleases every instructor in those courses. One approach that we have used in developing a custom-published text for a course with a group textbook decision is to include a "core body" of material to which everyone has agreed and then include various "supplementary chapters" that could be covered as independent modules if the 
instructors so desire. In this way, it is still possible to utilize a custom-published textbook to facilitate curriculum change when text selection is a group process.

\section{The use of custom-published textbooks as a mechanism to keep course content current}

A second key benefit of compiling and using a custom-published textbook is that the annual or biennial revision of the text keeps the course content more current than if we based the course on a traditional accounting text with a triennial revision schedule. Indeed, more than $80 \%$ of the material appearing in the 20012002 edition of our custom-published text is dated 2000 or later and all of the material is dated 1995 or later.

As a tradeoff, it may be difficult to find homework problems for cuttingedge topics, particularly if faculty members include non-traditional resources (e.g., professional publications) in the custom-published textbook. Indeed, this difficulty has resulted in our text including fewer problems than students normally find in other courses and resulted in one student commenting, "The text book was

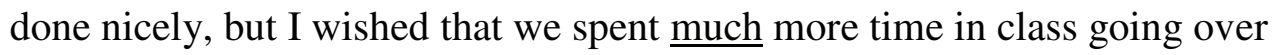
examples and problems." To overcome this problem, faculty can create custom homework sets, but this is an involved process. 


\section{The use of a variety of sources for information contained in custom-published} textbooks

The inclusion of a wide array of materials drawn from a broad spectrum of sources helps to broaden the course and increase its appeal to a wider spectrum of students. For instance, within our own university, our finance colleagues are encouraging their students to minor in accounting and take our Advanced Accounting course, which has resulted in an increase in the number of accounting minors from the finance department. In the fall of 1999, when we first offered the revised course, $23 \%$ of the senior finance majors chose to minor in accounting. By the 2001-2002 academic year, 44\% of the senior finance majors chose to minor in accounting.

On the other hand, some students find it difficult to assimilate information drawn from a multitude of sources. As one student noted, "The book and lectures contributed to my learning, however at times it was hard to follow the book because it was drawn from several different authors." While we have not found any way to overcome this pitfall, judging from comments on students' evaluation forms, the number of students for whom assimilation is a problem is fairly small, probably less than $10 \%$. Again, with $80 \%$ of responding students in the 20012002 academic year indicating that they agreed/strongly agreed that the textbook 
they bought for the class aided their learning, we do not believe this problem to be widespread.

\section{The cost-effectiveness of custom-published textbooks}

Finally, the use of a single custom-published text is generally more cost efficient for the students because students pay only for materials they use. Clearly, requiring students to purchase multiple texts of which only portions are relevant is not cost-effective for the students.

Five different textbooks drawn from two different publishers and seven professional/business sources provide the textual material for the course. The 2001-2002 edition of our custom-published textbook contained 566 pages in nine chapters. Our university's bookstore charged the students $\$ 99.50$ for the custompublished text. In comparison, three popular Advanced Accounting textbooks (i.e., Advanced Accounting texts by Baker, et al. [2002], Beams, et al. [2000] and Hoyle, et al [2001]) contain an average of 1014 pages in 20 chapters and would have had an average cost to the students of about $\$ 120.00$ through Amazon.com. Obviously, part of the cost differential between our custom-published textbook and the traditional texts results from the traditional text's inclusion of more pages covering more topical areas. Few professors cover all of the material in a traditional textbook in a semester, so traditional texts include several chaptersworth of information that the students purchase, but do not use. Thus, given the 
cost differential between our custom-published textbook and the traditional textbooks, it would appear (in Advanced Accounting, at least) that full use of a custom-published textbook is more cost effective for the students than is partial use of a single traditional textbook.

Nonetheless, after considering the market for students to resell their used texts, the difference in cost between a traditional textbook and a custom-published textbook may decrease or even disappear. That is, unless they are at the end of their publication cycle, traditional texts often have a ready resale market. In contrast, the resale market for custom-published textbooks may be limited or nonexistent.

On the downside, and perhaps most significantly, creating a custompublished text is very time-consuming. In the first year we used a custompublished text, each of us spent in excess of 100 hours on the creation of the book. Subsequent revisions have required an investment of 50 or more hours by each. Thus, committing to revise a custom-published text on an annual basis is a very serious time commitment. However, updating an upper-level course each year is frequently necessary, and some of the time we devote to updating the text is time we still would spend to update the course. 


\section{Summary}

There are many benefits associated with compiling a custom-published textbook. First, faculty can design the texts to support custom-created curriculum. Second, faculty can revise the text annually or biennially in order to keep course content current. Third, by using sources from other disciplines, faculty can broaden their courses and thereby increase the courses' appeal to a wider spectrum of students. Finally, by including only materials the students will use, faculty can create texts that are generally more cost effective for the students.

On the other hand, there are several challenges associated with compiling a custom-published textbook. First, it is difficult to adopt a custom-published textbook in courses taught by multiple professors. Second, readings that are drawn from non-traditional sources often lack practical (i.e., homework) problems. Third, some students have difficulty assimilating information drawn from multiple authors. Finally, compiling a custom-published textbook requires faculty to invest a great deal of time.

Based on our experiences, the benefits outweigh the costs. At a time when fewer students are studying accounting (Albrecht and Sack 2000, 19-21; Taylor Report 2000), our revised course, as supported by our custom-published text, has enjoyed tremendous growth. That is, enrollment in our Advanced Accounting course has risen steadily at our university despite a striking similarity in the size of the population of students eligible to take the course. In the fall 1999 semester, 
the first time we offered the revised course, but before students knew that we had revised the course, we offered two sections with 45 students. (Enrollments did not support offering the course during the spring 2000 semester.) By comparison, during the 2001-2002 academic year, our enrollment, as compared to the first year, more than doubled to 99 students who filled four sections.

\section{CONCLUSION}

In this paper, we have described the steps necessary to create a custompublished textbook. Using an example drawn from a successful revision of Advanced Accounting, we have shown how introducing a custom-published text can support meaningful curriculum revision. The introduction of a custompublished text is one technique that can be used to answer the calls from the leaders of the profession for changes in accounting education. Use of a custompublished textbook allows faculty to choose the course content and delivery so as to optimize the educational experience for the students at a given university in a given course. 


\section{ACKNOWLEDGMENTS}

The authors thank the Co-Editor, Bill Schwartz, and two anonymous referees for

their suggestions. We also appreciate helpful comments from Dennis Bline and participants at the Charles F. Dolan School of Business Research Workshop at Fairfield University. 


\section{NOTES}

1. The 2001 edition of our text contained 566 pages and was comprised of materials drawn from five textbooks (across two different publishers) and seven professional/business sources. Our university's bookstore charged the students $\$ 99.50$ for our custom-published text.

2. Note that while many professional publications (e.g., the Journal of Accountancy, Big 5 training materials, etc.) are available to educators free of royalties for classroom use, students still incur a minimal charge related to duplicating any such publications included in the custom-published textbook. 


\section{REFERENCES}

A critical analysis of advanced accounting issues. 2001. Selected Material for Massey and Van Hise's Advanced Accounting. (Authors' compilation of materials drawn from current professional publications and accounting textbooks) (Boston: McGraw-Hill Companies, Inc., Primis Custom Publishing).

Adelberg, A. H., J. R. Razek. 1984. The cloze procedure: a methodology for determining the understandibility of accounting textbooks. The Accounting Review. 59 (January): 109-122.

Accounting Education Change Commission (AECC). 1990. Objectives of education for accountants: Position statement number one. Issues in Accounting Education 5 (Fall): 307-312.

Albrecht, W. S. and R. J. Sack. 2000. Accounting education: Charting the course through a perilous future." A joint project of: AAA, AICPA, IMA, Arthur Andersen, Deloitte and Touche, Ernst and Young, KPMG, PricewaterhouseCoopers. In Accounting Education Series, Vol. 16. (Sarasota, FL: AAA).

American Institute of Certified Public Accountants (AICPA). 1999. Focus on the Horizon, the CPA Profession in 2011. (New York: AICPA).

American Institute of Certified Public Accountants (AICPA). 2000. VisionAligned Academic Framework. Available at: http://www.aicpa.org/edu/corecomp.htm.

Apostolou, B., S. F. Watson, J. M. Hassell and S. A. Webber. 2001. Accounting education literature review (1997-1999). Journal of Accounting Education, 19 (1): 1-61.

Armitage, J. L. 1991. Academicians' and practitioners' views on the content and importance of the advanced financial accounting course. Journal of Accounting Education, 9, (Fall): 327-340.

Baker, R. E., V. C. Lembke and T. E. King. 2002. Advanced Financial Accounting ( $5^{\text {th }}$ ed.). New York: McGraw-Hill Companies, Inc. 
Beams, F. A., J. A. Brozovsky, C. D. Shoulders. 2000. Advanced Accounting $\left(7^{\text {th }}\right.$ ed.). New York: Prentice-Hall.

Bedford Committee. 1986. Future Accounting Education: Preparing for the Expanding Profession. (Sarasota, FL: AAA).

Big 8. 1989. Perspectives on Education: Capabilities for Success in the Accounting Profession. (New York: Big 8).

Birnberg, J. G. 2000. The role of behavioral research in management accounting education in the $21^{\text {st }}$ century. Issues in Accounting Education 14 (November): 713-728.

Böer, G. 2000. Management Accounting Education: Yesterday, Today and Tomorrow. Issues in Accounting Education 15 (May): 313-334.

Catanach, Jr., A. H., Croll, D. B., Grinaker, R. L. 2000. Teaching intermediate financial accounting using a business activity model. Issues in Accounting Education, 14 (November): 583-603.

Cohen, J. R., L. W. Pant, and D. J. Sharp. 2000. Project earnings manipulation: an ethics case based on agency theory. Issues in Accounting Education 15 (February): 89-104.

Cunningham, B. M. 1996. How to restructure an accounting course to enhance creative and critical thinking. Accounting Education, 1(1): 49-66.

Farr, R. 1987. Textbook selection and curriculum change. The Journal of State Government. 60 (March/April): 86-91.

Foran, M. F., P. R. Olds. 2002. Using the Wall Street Journal and the Internet to implement the AECC's introductory accounting recommendations. Advances in Accounting Education, 4: 21-39.

Hoyle, J. B., T. F. Schaefer and T. S. Doupnik. 2001. Advanced Accounting $\left(6^{\text {th }}\right.$ ed.). New York: Irwin/McGraw-Hill.

Hwang, Angela L. J. and J. S. Patouhas. 2001. Practical Issues in Implementing FASB 133. Journal of Accountancy. Mar: 26-34. 
Institute of Management Accountants (IMA). 1994. What America Wants in Entry-Level Accountants. (Montvale, NJ: IMA).

Institute of Management Accountants (IMA). 1999. Counting More, Counting Less: Transformations in the Management Accounting Profession. (Montvale, NJ: IMA).

Ketz, J. E. and P. B. W. Miller. 1996. College texts so full of rules they can't teach real life. Accounting Today 10 (August 26): 14-15.

Kimmel, P. 1995. A framework for incorporating critical thinking into accounting education. Journal of Accounting Education, 13(3): 299-318.

Knechel, W. R. 2000. Behavioral research in auditing and its impact on audit education. Issues in Accounting Education 15 (November): 695-712.

KPMG, LLP. 1998. Derivatives and Hedging Handbook. Montvale, NJ: KPMG, LLP.

Massey, D. and J. Van Hise. 2001. "Revising the Advanced Accounting curriculum." Canadian Accounting Education and Research News. (Autumn): 12-13, 23.

McCarthy, E. 2000. Derivatives revisited. Journal of Accountancy. May: 35-43.

McConnell, P., J. Pegg, D. Zion. 2001. Accounting issues: The end is here. In Goodbye, Goodwill edited by Bear, Stearns \& Co., Inc. (June): 7-9 (NY: Bear, Stearns \& Co., Inc.)

Molvar, R. H. D. and J. F. Green. 1995. The question of derivatives. Journal of Accountancy. March: 55-61.

Novin, A. M., D. F. Fetyko, and J. M. Tucker. 1997. Perceptions of accounting educators and public accounting practitioners on the composition of 150hour accounting programs: a comparison. Issues in Accounting Education 12 (Fall): 331-352.

Radebaugh, S. and L. Gray. 1997. International Accounting and Multinational Enterprises $\left(4^{\text {th }}\right.$ ed.). NY: John Wiley \& Sons, Inc. 
Razek, J. R., G. A. Hosch, and D. Pearl. 1982. Readability of accounting textbooks. Journal of Business Education (October): 23-26.

Rebele, J. E., B. A. Apostolou, F. A. Buckless, J. M. Hassell, L. R. Paquette, D. E. Stout. 1998. Accounting education literature review (1991-1997), part I: Curriculum and instructional approaches. Journal of Accounting Education, 16 (1): 1-51.

Robert Half International Inc. 2001. Next Generation Accountant: New Competencies, Converging Disciplines, Expanding Roles. (Menlo Park, CA: Robert Half International Inc.)

Schweikart, J. A., S. J. Gray and C. B. Roberts. 1995. International Accounting: A Case Approach. New York: McGraw-Hill Companies, Inc.

Smith, K. J. and J. J. DeRidder. 1997. The selection process for accounting textbooks: general criteria and publisher incentives-a survey. Issues in Accounting Education 12 (Fall): 367-384.

Smith, G. S. and C. W. Smith. (1991). A working paper of a model of undergraduate accounting education for life-long learning. In G. L. Sundem and C. T. Norgaard, (Eds.), Models of Accounting Education: Proceedings of a Symposium Sponsored by the Accounting Education Change Commission and the Accounting Education Advisory Committee of the American Accounting Association. Torrance, CA: Accounting Education Change Commission, 14-32.

Spiceland, J. D., J. F. Sepe and L. A. Tomassini. 2001. Intermediate Accounting: Volume I ( $2^{\text {nd }}$ ed. $)$. NY: Irwin/McGraw-Hill.

Stone, M. 2001. Building human and social capital. Accounting Education News (Spring): 1-2, 11.

Stout, D. and J. Schweikart. 1989. The relevance of international accounting to the accounting curriculum: A comparison of practioner and educator opinion. Issues in Accounting Education (Spring): 126-141.

Taylor Research and Consulting Group, Inc (Taylor Report). (2000). Student and Academic Research Study: Final Report. (New York: AICPA). 
Tully, S. 1999. The earnings illusion: Ever wonder why so many mergers make the CEO look like superman? Odds are, it's not the strategic fit. It's the accounting" Fortune. April 26: 206-210.

Wilson, A., G. Waters and B. J. Bryan. 1998. The decision on derivatives. Journal of Accountancy. November: 24-29. 


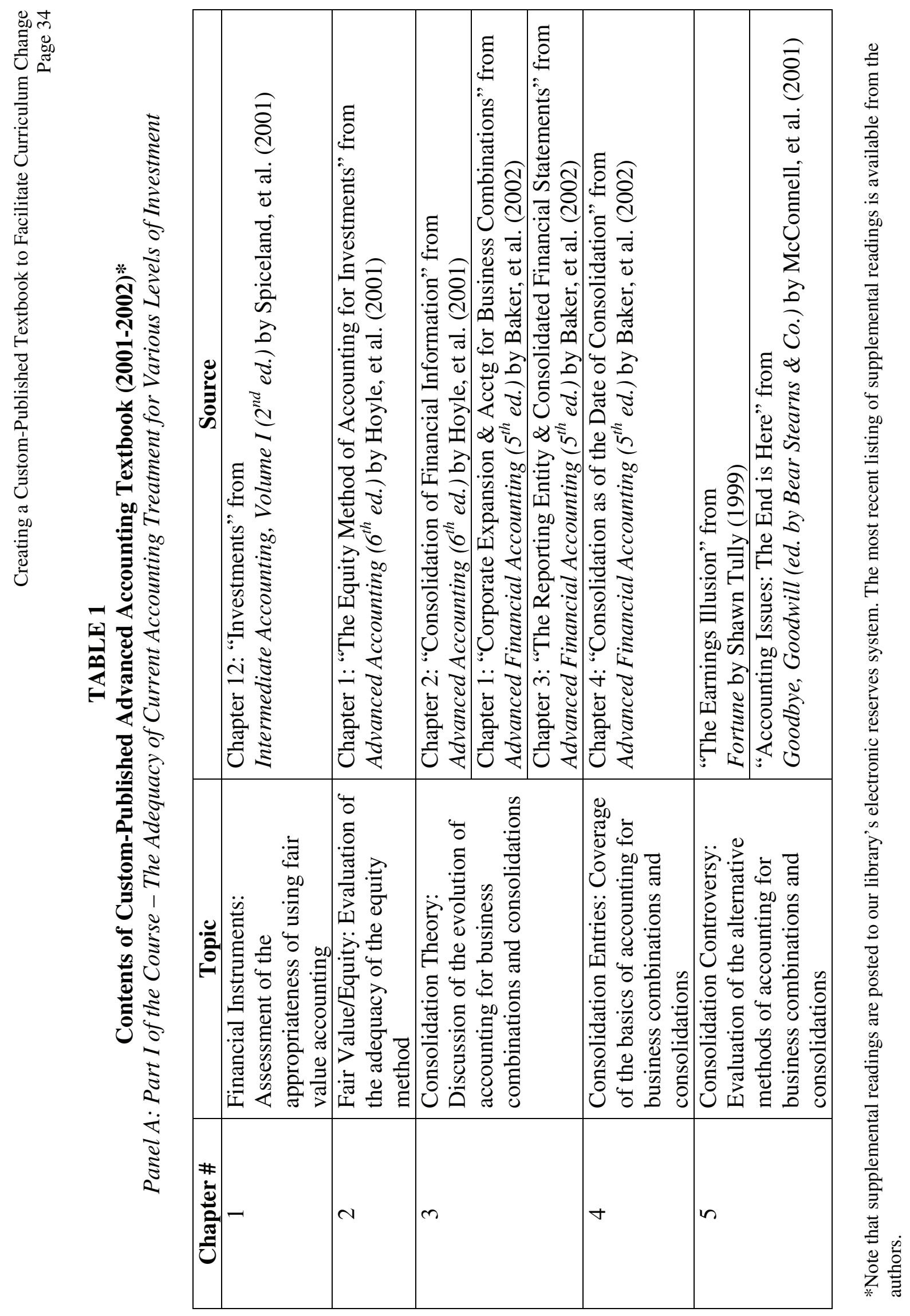




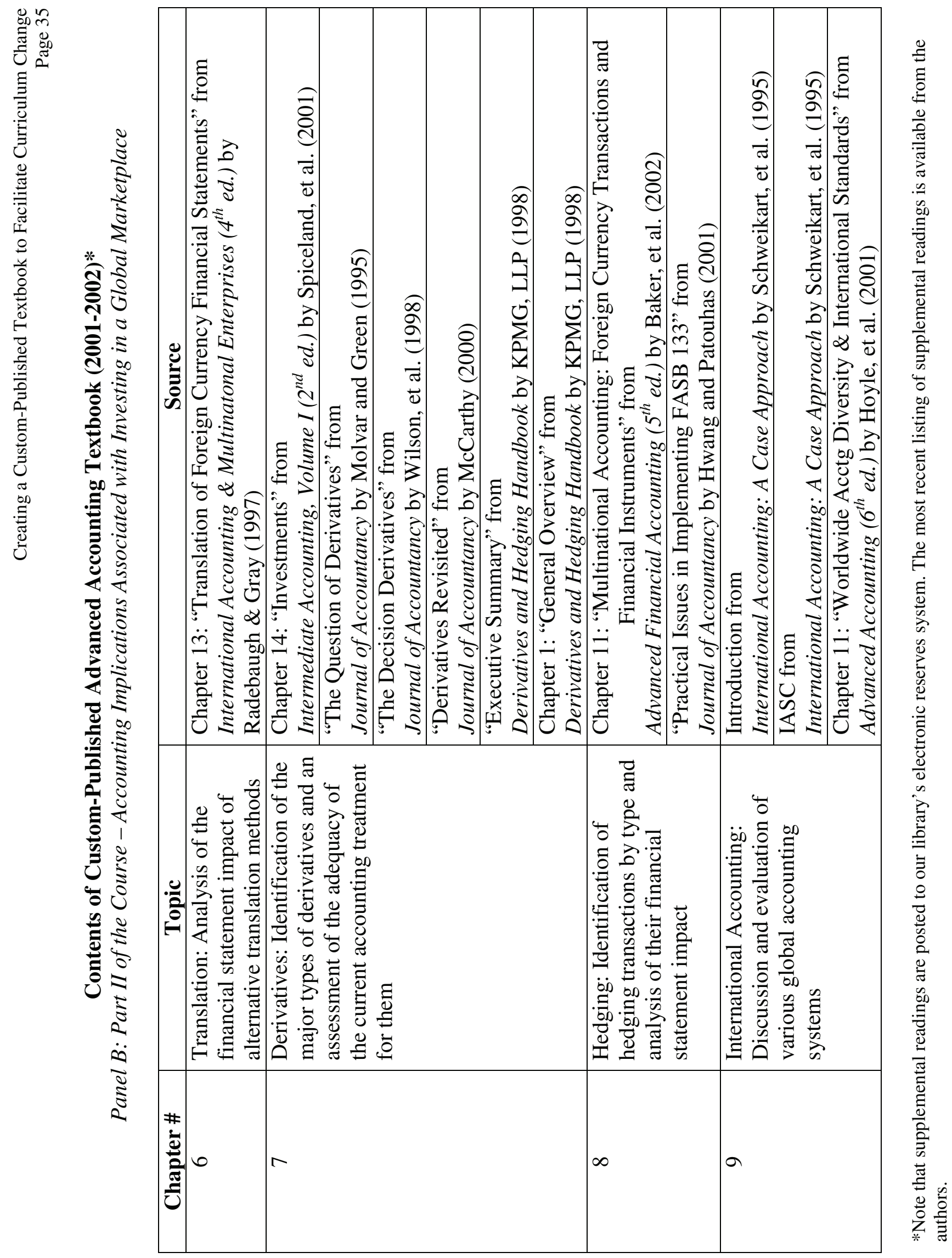

